\title{
Effects of double emulsification on Lactobacillus plantarum NBRC 3070 stability and physicochemical properties of soursop juice during storage
}

\author{
Safiah Sabrina Hassan ${ }^{a}$, Intan Nabihah Ahmad Fadzil ${ }^{a}$, Hifa Nazirah Mohammed Yazid ${ }^{a}$, Anida Yusoff \\ Khalilah Abdul Khalil ${ }^{*}$ \\ aschool of Biology, Faculty of Applied Sciences, Universiti Teknologi MARA, 40450 Shah Alam, Selangor, Malaysia \\ ${ }^{b}$ School of Industrial Technology, Faculty of Applied Sciences, Universiti Teknologi MARA, 40450 Shah Alam, Selangor, Malaysia
}

Received 6th March 2020 / Accepted 10th August 2020

\begin{abstract}
Sufficient number of probiotics in product are required to confer its health benefits to consumers. However, the viability of probiotics can detriment during processing. An approach of emulsion method to provide a physical barrier of probiotics against adverse environmental conditions has received considerable level of interest. Various matrices were used to emulsified probiotics in food product. However, the usage of water/oil/water $\left(\mathrm{W}_{1} / \mathrm{O} / \mathrm{W}_{2}\right)$ base to emulsify probiotics for beverages application remained scarce. Thus, this study was to determine the suitability of using $\mathrm{W}_{1} / \mathrm{O} / \mathrm{W}_{2}$ base to emulsify Lactobacillus plantarum NBRC 3070 to be incorporated into pasteurized soursop juice (Annona muricata L.). Hence, emulsion efficiency (EE\%) of L. plantarum NBRC 3070 in $\mathrm{W}_{1} / \mathrm{O} / \mathrm{W}_{2}$ base, the stability of emulsified cells $\left(\log _{10} \mathrm{CFU} / \mathrm{mL}\right)$ and physicochemical changes of soursop juice $(\mathrm{pH}$, titratable acidity, total soluble solid, viscosity, colour, sensory) during storage were determined. In this study, emulsified $L$. plantarum NBRC $3070\left(10^{9} \mathrm{CFU} / \mathrm{mL}\right)$ was incorporated into soursop juice and stored at $4^{\circ} \mathrm{C}$ for four weeks. Results obtained with $86.02 \% \pm 0.69$ emulsion efficiency $(\%)$ of $L$. plantarum NBRC 3070. Insignificant changes $(\mathrm{p}>0.05)$ were notified from viability of emulsified probiotics, $\mathrm{pH}$, titratable acidity and viscosity during storage. Meanwhile, satisfactory parameters (colour, sensory and coliform counts) were obtained at the satisfactory level. As for the conclusion, $\mathrm{W}_{1} / \mathrm{O} / \mathrm{W}_{2}$ base was able to maintain the survivability of $L$. plantarum NBRC 3070 in soursop juice during storage and quality of the product. Optimization of parameters such as water/oil compositions and storage time can be further explored to enhance product quality.
\end{abstract}

Keywords: Double emulsion, L. plantarum, physicochemical characteristics, soursop, storage

\section{INTRODUCTION}

According to Food and Agriculture Organization (FAO) of the United Nations and the World Health Organization (WHO), probiotics can be defined as "Live microorganisms (bacteria or yeasts), which when ingested or locally applied in sufficient numbers confer one or more expected health benefits for the host" (FAO/WHO, 2002).
Lactobacillus and Bifidobacterium are among the common probiotics reported. However, some species from Bacillus, Pediococcus, and yeasts have also been found as suitable candidates. Due to perceiving health benefits, probiotics have been increasingly incorporated into several functional foods such as yogurts, cheese, ice cream, desserts,

*Author for correspondence: Khalilah Abdul Khalil, School of Biology, Faculty of Applied Sciences, Universiti Teknologi MARA, 40450 Shah Alam, Selangor, Malaysia. Email - khali552@uitm.edu.my 
and others (Stanton et al., 2005). Several health benefits of probiotics have been reported such as alleviation of lactose, intolerance to nutritional enhancement, anti-infection properties, immune system stimulation, serum cholesterol reduction, anti-carcinogenic properties, and others (Mombelli and Gismondo, 2000). Nevertheless, the benefits can only be exhibited if the dose level and their viability can be maintained throughout the storage period, product shelf-life (Kailasapathy et al., 2000), and in the gut environment of the host (Khalil et al., 2019). It has been recommended that the daily intake of probiotics required a minimum amount of $10^{6}$ $\mathrm{CFU} / \mathrm{g}$ of food products or $10^{7}$ to $10^{8} \mathrm{CFU} / \mathrm{g}$ upon consumption (Lopez-Rubio et al., 2006). However, there are still limitations with respect to the low viability of probiotic in products and upon reaching the target area.

Therefore, microencapsulation technique has been used as a solution to improve microorganism resistance during their storage and/or passage through the gastrointestinal tract under low acidic conditions (Mokhtari et al., 2018). Microencapsulation of bacterial cells through emulsion approach involves a mild process that is not detrimental to cells and can be scaled up easily (Ding and Shah, 2008). Double emulsion, which is also known as water-in-oil-in-water $\left(\mathrm{W}_{1} / \mathrm{O} / \mathrm{W}_{2}\right)$ emulsion, are multi-compartmentalized systems in which the inner aqueous phase $\left(\mathrm{W}_{1}\right)$ is dispersed into the oil phase and then subsequently into the outer aqueous phase $\left(\mathrm{W}_{2}\right)($ Cofrades et al., 2013; Safiah et al., 2020). The encapsulation of probiotics in double emulsion helps in enhancing cells viability in functional food products during the storage period (El-Kadri et al., 2018). Currently, research on functional food supplemented with probiotics is gaining attention.

Fruit juice can be an ideal carrier for probiotics since it is a great source of sugars, nutrients, and free from other starter cultures that may compete with probiotics for nutrients (Fernandes Pereira and Rodrigues, 2018). In addition, fruit juices also facilitate anaerobic conditions due to the presence of oxygenscavenging elements such as ascorbic acid (Ding and Shah, 2008). However, studies on the incorporation of probiotics into fruit juices remained scarce and need to be explored. Therefore, the application of double emulsified probiotic (L. plantarum NBRC 3070) into fruit juices (pasteurized extracted soursop) was explored in this study. The aim of this study was to determine the emulsion efficiency of $L$. plantarum NBRC 3070 in double emulsion $\left(\mathrm{W}_{1} / \mathrm{O} / \mathrm{W}_{2}\right.$ base), the stability of emulsified probiotic in soursop juice, and the physicochemical characteristics of soursop juice ( $\mathrm{pH}$, titratable acidity, total soluble solid [TSS], viscosity, colour, sensory) after incorporated with emulsified L. plantarum NBRC 3070 during storage.

\section{MATERIALS AND METHODS}

\section{Preparation of soursop juice}

Fresh soursops were purchased from supermarkets in Selangor, Malaysia. The soursops were washed, hand peeled, and deseeded. The pulp was obtained by blending with sterile distilled water in a ratio of 1:2 (w/v, pulp/water). Soursop juice was extracted by filtering with a sterile muslin cloth (Akpeji et al., 2017). Next, the extracted juice was poured into a sterile bottle and pasteurized at a temperature of $79^{\circ} \mathrm{C}$ for 69 seconds (Abbo et al., 2006).

\section{Preparation of emulsified L. plantarum NBRC 3070 using double emulsion layers}

By using a method adopted from El-Kadri et al. (2016) with minor modification, the double emulsion was prepared at room temperature using a combination of water-in-oil-in-water (W1/O/W2) and probe homogenizer (Ika, Malaysia), which was used in order to ensure the mixture were well-mixed. Firstly, water in oil emulsion $\left(\mathrm{W}_{1} / \mathrm{O}\right)$ was prepared with a ratio of 40:60 by dissolving approximately $2 \% \quad(\mathrm{v} / \mathrm{v})$ polyglycerol polyricinoleate (PGPR) (Danisco, Denmark), which acted as an emulsifier, into corn oil as an oil phase $(\mathrm{O})$. The inner aqueous phase (W1) which consisted of deionized water was prepared by adding $10 \%(\mathrm{v} / \mathrm{v})$ of $10^{\circ} \mathrm{CFU} / \mathrm{mL} \mathrm{L}$. plantarum NBRC 3070 and 1\% (v/v) inulin (Sigma Aldrich, USA) as prebiotic. The mixture was then added to the oil phase and well-mixed by homogenizing for two minutes at 4,000 rpm to obtain a single emulsion layer $\left(\mathrm{W}_{1} / \mathrm{O}\right)$. 
Subsequently, double emulsion was obtained by adding the single emulsion (W1/O) into deionized water containing $8 \%(\mathrm{v} / \mathrm{v})$ of Tween 80 (Sigma Aldrich, United Kingdom), which acted as the second aqueous phase (W2). The double emulsion was prepared in a ratio of 20:80 $\left(\mathrm{W}_{1} / \mathrm{O}\right.$ : $\mathrm{W}_{2}$ ). The mixture was well-mixed by homogenizing at 3,000 $\mathrm{rpm}$ for one minute. The emulsified L. plantarum NBRC 3070 was then stored at $4^{\circ} \mathrm{C}$ for further application.

\section{Preparation of soursop juice supplemented with emulsified L. plantarum NBRC 3070}

Approximately $10 \% \quad(\mathrm{v} / \mathrm{v})$ of emulsified $L$. plantarum NBRC 3070 was added into the pasteurized soursop juice. Subsequently, the soursop juice incorporated with emulsified $L$. plantarum NBRC 3070 was stored at $4^{\circ} \mathrm{C}$ for four additional weeks and sampling was carried out on weekly intervals. The pure soursop juice which does not contain emulsified L. plantarum NBRC 3070 and the soursop juice with free cells were used as control.

\section{Analysis}

\section{Emulsion efficiency of L. plantarum NBRC 3070 (EY\%)}

Using a method by El-Kadri et al. (2016) with minor modification, the serum phase on the emulsion layer was removed with a syringe. The viability of $L$. plantarum NBRC 3070 in the serum phase was measured by performing serial dilution in phosphate buffer solution (PBS) and plating on MRS agar. The emulsion efficiency was calculated by using the equation below.

$$
\text { Emulsion efficiency (\%): } \frac{\mathrm{N}_{0}-\mathrm{N}}{\mathrm{N}_{0}} \times 100 \%
$$

Where $\mathrm{N}$ is the number of free viable $L$. plantarum NBRC 3070 cells after forming the double emulsion and N0 indicates the free viable $L$. plantarum NBRC 3070 cells before encapsulation in the double emulsion.

Viability of emulsified L. plantarum NBRC 3070 in soursop juice during storage

By adopting a method from De Almeida Paula et al. (2019) with minor modification, the emulsified $L$. plantarum NBRC 3070 soursop juice was homogenized in a peptone saline solution to obtain serial dilutions. A volume of $0.1 \mathrm{~mL}$ emulsified probiotic soursop juice was transferred onto MRS agar plates using spread plate technique and incubated anaerobically for 48 hours at $37^{\circ} \mathrm{C}$. After the incubation period, the colonies were counted and the data was expressed in number of colonies forming unit per millilitre of juice (CFU $\left.\mathrm{mL}^{-1}\right)$. The viability determination was conducted on a weekly interval for four weeks.

Microbiological quality and physicochemical characteristics of soursop juice incorporated with emulsified L. plantarum NBRC 3070

\section{i) Microbiological quality: coliform, yeast, and mould counts of soursop juice incorporated with emulsified $L$. plantarum NBRC 3070}

Approximately $1 \mathrm{~mL}$ of the soursop juice incorporated with emulsified L. plantarum NBRC 3070 was obtained on weekly intervals for four weeks and serial dilution was performed in triplicates with sterilized peptone solution and plated onto agar using the spread plate technique. Yeast and mould counts of the emulsified probiotic soursop juice were determined by using Potato Dextrose Agar (PDA) at $30^{\circ} \mathrm{C}$ for five days. Meanwhile, the coliform count was performed on MacConkey Agar and incubated at $37^{\circ} \mathrm{C}$ for 24 hours (Braide et al., 2012).

\section{ii) Physicochemical determination of soursop juice incorporated with emulsified $L$. plantarum NBRC 3070 during storage}

The soursop juice incorporated with emulsified $L$. plantarum NBRC 3070 was stored at $4^{\circ} \mathrm{C}$ for four weeks and was further analysed for $\mathrm{pH}$, titratable acidity (\% of malic acid), TSS ( ${ }^{\circ}$ Brix), viscosity, and colour evaluation on weekly intervals. The sensory evaluation by using nine hedonic scales was only conducted on the soursop juice incorporated with emulsified L. plantarum NBRC 3070 on the final week of storage.

\section{a) $\mathrm{pH}$ evaluation}

The $\mathrm{pH}$ of the soursop juice incorporated with emulsified L. plantarum NBRC 3070 was determined by using a $\mathrm{pH}$ meter (Hanna, Singapore). 


\section{b) Titratable acidity}

By using a method provided by Gamage et al. (2016), the presence of predominant acid (malic acid) in the soursop juice incorporated with emulsified probiotic was determined by titrating $10 \mathrm{~mL}$ of the soursop juice with $0.1 \mathrm{~mol} / \mathrm{L}$ $\mathrm{NaOH}$. An approximate volume of $1 \mathrm{~mL}$ phenolphthalein was used as an indicator.

\section{c) Total soluble solid}

The TSS of the soursop juice incorporated with emulsified L. plantarum NBRC 3070 during storage was determined by using a hand refractometer (Abbe, Japan), which was based on the method proposed by Akpeji et al. (2017).

\section{d) Viscosity}

The viscosity of the soursop juice incorporated with emulsified L. plantarum NBRC 3070 was measured by using a viscometer (Brookfield, USA) (Minh et al., 2019).

\section{e) Colour evaluation}

The colour of the soursop juice incorporated with emulsified L. plantarum NBRC 3070 was evaluated by using a colorimeter (Kinoca Minolta, Japan), which focused on the colour parameters such as Hunter L*, a*, and $b^{*}$ values (Lizasoain et al., 2015).

\section{f) Sensory evaluation}

The sensory evaluation of the soursop juice incorporated with emulsified L. plantarum NBRC 3070 was conducted by 35 untrained sensory panellists. The pure soursop juice that did not contain any probiotic was used as a control for this sensory evaluation. Nine hedonic scale which indicates the degree of preference was used to evaluate the colour, viscosity, odour, taste, and overall acceptability of the sample. Approximately $50 \mathrm{~mL}$ of each sample was presented to the sensory panellists with three random identity codes. The samples from week zero to week four of storage were used for sensory evaluation. The samples were chilled at a refrigerated temperature of $4^{\circ} \mathrm{C}$ prior to serving. The evaluation of nine hedonic scale was presented on a scale ranging from dislike extremely (1), moderate (5), and like extremely (9). The statistical analysis of the sensory evaluation was analysed by using one-way ANOVA (SPSS Statistic 22 Software), in which

the difference between means was separated by using Duncan's Multiple Ranged Test (Rathod, 2017).

\section{Statistical analysis}

All the results which were performed in triplicates were used to calculate the mean for the data obtained. The normality of data was inspected by using the Shapiro-Wilk test prior to statistical analysis. Analysis of variance was conducted by using one-way ANOVA and the significant difference between the means of data was determined using Tukey's test (Silva and Ferrari, 2016).

\section{RESULTS AND DISCUSSION}

Emulsion efficiency of emulsified $L$. plantarum NBRC 3070 prior to incorporation into soursop juice

The emulsion efficiency (EE\%) of L. plantarum NBRC 3070 obtained from this study was $86.02 \%$ \pm 0.69 (Table 1). The results of this study showed high emulsion efficiency and were agreed with previous studies which reported that the acceptable $\mathrm{EE} \%$ range was between $80 \%$ and 95\% (Krasaekoopt et al., 2003, Pimentel-Gonzales et al., 2009, Tee et al., 2013). The double emulsion approach used in this study was able to capture a high percentage of L. plantarum NBRC 3070 during mixing. This suggested that the mixture of oil, water, Tween80, and polyglycerol polyricinoleate (PGPR) as emulsifier were able to assist the entrapment of probiotics in the matrices. However, different matrices had resulted in different $\mathrm{EE} \%$ of probiotics.

Table 1. Emulsion efficiency $(\mathrm{EE} \%)$ of $L$. plantarum NBRC 3070 in Water $_{1} /$ Oil/ Water $\left(\mathrm{W}_{1} / \mathrm{O} / \mathrm{W}_{2}\right)$ matrices.

Emulsion Matrices

Emulsion Efficiency

(\%)
Water $_{1} /$ Oil/ Water 2

$86.02 \pm 0.69$

$\mathrm{W}_{1} / \mathrm{O}: \mathrm{W}_{2}$ in $20: 80$ ratio containing a combination of $1 \%$ inulin, 2\% PGPR, and $8 \%$ Tween 80 . 
The stability of emulsified L. plantarum NBRC 3070 in soursop juice during storage

The stability of the emulsified L. plantarum NBRC 3070 within the double emulsion matrices in the soursop juice during storage is shown in Figure 1. The result showed no significant reduction ( $p>0.05$ ) of the emulsified L. plantarum NBRC 3070 in the soursop juice ranging from $7.87 \log _{10}$ $\mathrm{CFU} \mathrm{mL} \mathrm{m}^{-1}$ to $7.01 \log _{10} \mathrm{CFU} \mathrm{mL} \mathrm{m}^{-1}$ throughout the storage period. As compared to that of the control, it was observed that the free cells decreased significantly $(p<0.05)$ from $7.89 \log _{10}$ CFU mL $\mathrm{mL}^{-1}$ to $4.90 \log _{10} \mathrm{CFU} \mathrm{mL} \mathrm{mL}^{-1}$ during storage. This indicates that the emulsion of $L$. plantarum NBRC 3070 is able to serve as a barrier to protect the cells from extreme external environment of soursop juice such as acidic $\mathrm{pH}$ which can be detrimental for their survival. This finding was similar to that of Horackova et al. (2018), in which the emulsified Bifidobacterium animalis subsp. lactis Bb12 in pineapple juice was reported to have shown slow cell reduction $(\mathrm{p}>0.05)$ during three weeks of storage at $8^{\circ} \mathrm{C}$. In addition, Phromthep and Leenanon (2017) had reported that the immobilized L. plantarum within bacterial cellulose cube in mamao juice showed no significant reduction ( $\mathrm{p}>0.05$ ) from $8.35 \log _{10} \mathrm{CFU} \mathrm{mL} \mathrm{mL}^{-1}$ to $6.41 \log _{10} \mathrm{CFU} \mathrm{mL} \mathrm{m}^{-1}$ at the end of the storage period of 28 days. The stability of probiotics in the product during storage is crucial to preserve its beneficial effects for the consumer upon consumption. According to $\mathrm{WHO}$ and FAO (2002), probiotics need to be at least $10^{6} \mathrm{CFU} \mathrm{mL}$ ${ }^{1}$ upon consumption to exhibit its benefits.

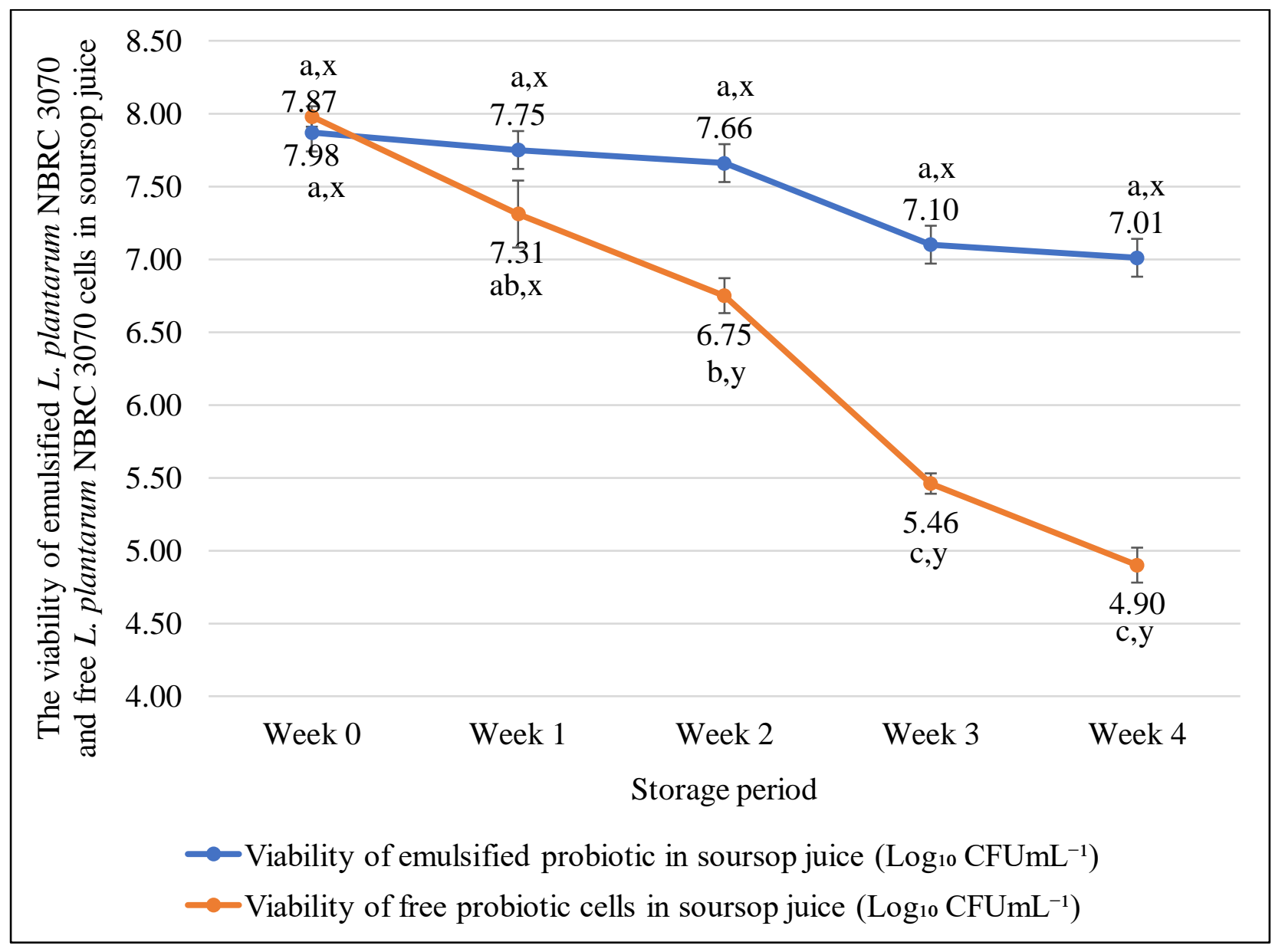

Figure 1. The viability of emulsified L. plantarum NBRC 3070 and free L. plantarum NBRC 3070 cells in soursop juice during storage at $4^{\circ} \mathrm{C}$ for 4 weeks. Values are mean based on triplicate experiments. Error bars represent standard deviations $(\mathrm{SD})$ of the mean values. $a-b$ : significantly different $(\mathrm{p}<0.05)$ within group. $x-y$ : significantly different $(p<0.05)$ between group. 


\section{Microbiological quality of soursop juice incorporated with emulsified L. plantarum NBRC 3070}

The microbiological quality of the soursop juice incorporated with emulsified L. plantarum NBRC 3070 is shown in Table 2. It was observed that there was no coliform count detected in the soursop juice during the storage period. The absence of coliform count in the soursop juice incorporated with emulsified L. plantarum NBRC 3070 indicates hygienic practices were adopted during the processing of the juice. This finding was aligned with the previous studies reported by Abbo et al. (2006) and Ndife et al. (2014), which showed no coliform growth in the pure pasteurized soursop juice during storage for eight weeks at $4^{\circ} \mathrm{C}$.

Meanwhile, a significant increase $(\mathrm{p}<0.05)$ in yeast count of both the control and soursop juice incorporated with emulsified L. plantarum NBRC 3070 were detected as early as on the first week of storage (Table 2). The yeast count of the soursop juice incorporated with emulsified $L$. plantarum NBRC 3070 was $5.59 \log _{10} \mathrm{CFU} \mathrm{mL} \mathrm{mL}^{-1}$, which is deemed acceptable according to Ampofo-Asiama and Quaye (2018). The presence of yeast in the juice may be caused by the presence of sugar and acidic condition in the soursop juice, which was favourable for the growth of the yeast. In addition, the yeast which was initially in the soursop juice may contribute to a load of yeast present in the juice.

According to US-FDA (2017), yeasts that internalized into the fruit might be present in the final products as they might survive the processing of products. Okwulehie and Alfred (2010) had reported that yeasts such as Saccharomyces cerevisiae, Candida albicans, and Torulopsis sp. and moulds such as Penicillium chrysogenum and Aspergillus niger were isolated from ripe soursop pulp. However, the absence of mould count was noticed in the double emulsified soursop juice throughout the storage period in this study (Table 2).

Table 2. Coliform, yeast and mold counts $\left(\log 10 \mathrm{cfuml}^{-1}\right)$ of soursop juice samples during storage at $4^{\circ} \mathrm{C}$ for 4 weeks.

Samples Control pure soursop juice

Soursop juice with emulsified L. plantarum NBRC 3070

\begin{tabular}{ccccccc}
\hline Weeks & $\begin{array}{c}\text { Coliform } \\
\text { count }\end{array}$ & Yeast counts & $\begin{array}{c}\text { Mold } \\
\text { counts }\end{array}$ & $\begin{array}{c}\text { Coliform } \\
\text { counts }\end{array}$ & Yeast counts & Mold counts \\
\hline Week 0 & ND & $<1.00 \pm 0.00^{\mathrm{a}, \mathrm{x}}$ & ND & ND & $<1.00 \pm 0.00^{\mathrm{a}, \mathrm{x}}$ & ND \\
Week 1 & ND & $4.48 \pm 0.44^{\mathrm{b}, \mathrm{x}}$ & ND & ND & $4.43 \pm 0.54^{\mathrm{b}, \mathrm{x}}$ & ND \\
Week 2 & ND & $5.06 \pm 0.57^{\mathrm{b}, \mathrm{x}}$ & ND & ND & $5.34 \pm 0.95^{\mathrm{b}, \mathrm{x}}$ & ND \\
Week 3 & ND & $5.40 \pm 0.54^{\mathrm{b}, \mathrm{x}}$ & ND & ND & $5.47 \pm 0.05^{\mathrm{b}, \mathrm{x}}$ & ND \\
Week 4 & ND & $5.59 \pm 0.48^{\mathrm{b}, \mathrm{x}}$ & ND & ND & $5.51 \pm 0.79^{\mathrm{b}, \mathrm{x}}$ & ND
\end{tabular}

Values are mean based on triplicate experiments. ND indicate non-detectable. Symbol ( \pm ) indicate standard deviation of data obtained. Different superscript letters indicate significant different at $\mathrm{p}<0.05$.

$a-b$ : significantly different $(p<0.05)$ by column. $x-y$ : significantly different $(p<0.05)$ by row.

\section{The physicochemical changes of soursop juice incorporated with emulsified $L$. plantarum NBRC 3070 during storage}

\section{a) $\mathrm{pH}$ changes}

The $\mathrm{pH}$ of the double emulsified L. plantarum NBRC 3070 soursop juice is shown in Figure 2. Generally, the $\mathrm{pH}$ for the soursop juice which contained emulsified probiotic, free cells, and pure soursop juice ranged from $\mathrm{pH} 3.95$ to $\mathrm{pH}$
4.08, $\mathrm{pH} 3.68$ to $\mathrm{pH} 4.04$, and $\mathrm{pH} 4.00$ to $\mathrm{pH} 4.05$ respectively. The decreasing trend in the $\mathrm{pH}$ of the soursop juice containing emulsified probiotic and free cells during the storage period may indicate weak metabolic activity of probiotics at $4^{\circ} \mathrm{C}$. However, the changes in $\mathrm{pH}$ were not significant $(p>0.05)$ in all groups (soursop juices incorporated with emulsified L. plantarum NBRC 3070, soursop juices with free L. plantarum NBRC 
3070 cells, and pure soursop juices) throughout the four weeks of storage.

This finding agreed with the previous study reported by Phromthep and Leenanon (2017) on the $\mathrm{pH}$ of the mamao juice containing immobilized L. plantarum cells within bacterial cellulose cubes which showed no significant difference during the storage for 28 days at $4^{\circ} \mathrm{C}$. The study had revealed that the mamao juice containing immobilized probiotics had $\mathrm{pH}$ value of $\mathrm{pH} 3.15$ on day zero and $\mathrm{pH} 3.18$ on day 28 of storage. Moreover, Antunes et al. (2013) had reported that there was no significant change in the $\mathrm{pH}$ of the acerola nectar supplemented with microencapsulated Bifidobacterium animalis cells during the storage for 35 days at $5^{\circ} \mathrm{C}$ with $\mathrm{pH}$ value of $\mathrm{pH} 3.60$ on day zero and $\mathrm{pH} 3.62$ on day 35.

The $\mathrm{pH}$ of the soursop juice containing double emulsified probiotic showed no significant difference $(\mathrm{p}>0.05)$ with the $\mathrm{pH}$ of the soursop juice containing free cells at week zero, but it was significantly different $(p<0.05)$ to that of the pure soursop juice. There was no significant difference recorded between the soursop juice samples on the remaining storage period. This result indicates that the incorporation of probiotics may contribute to the low $\mathrm{pH}$ of the juice in the early stage of storage.

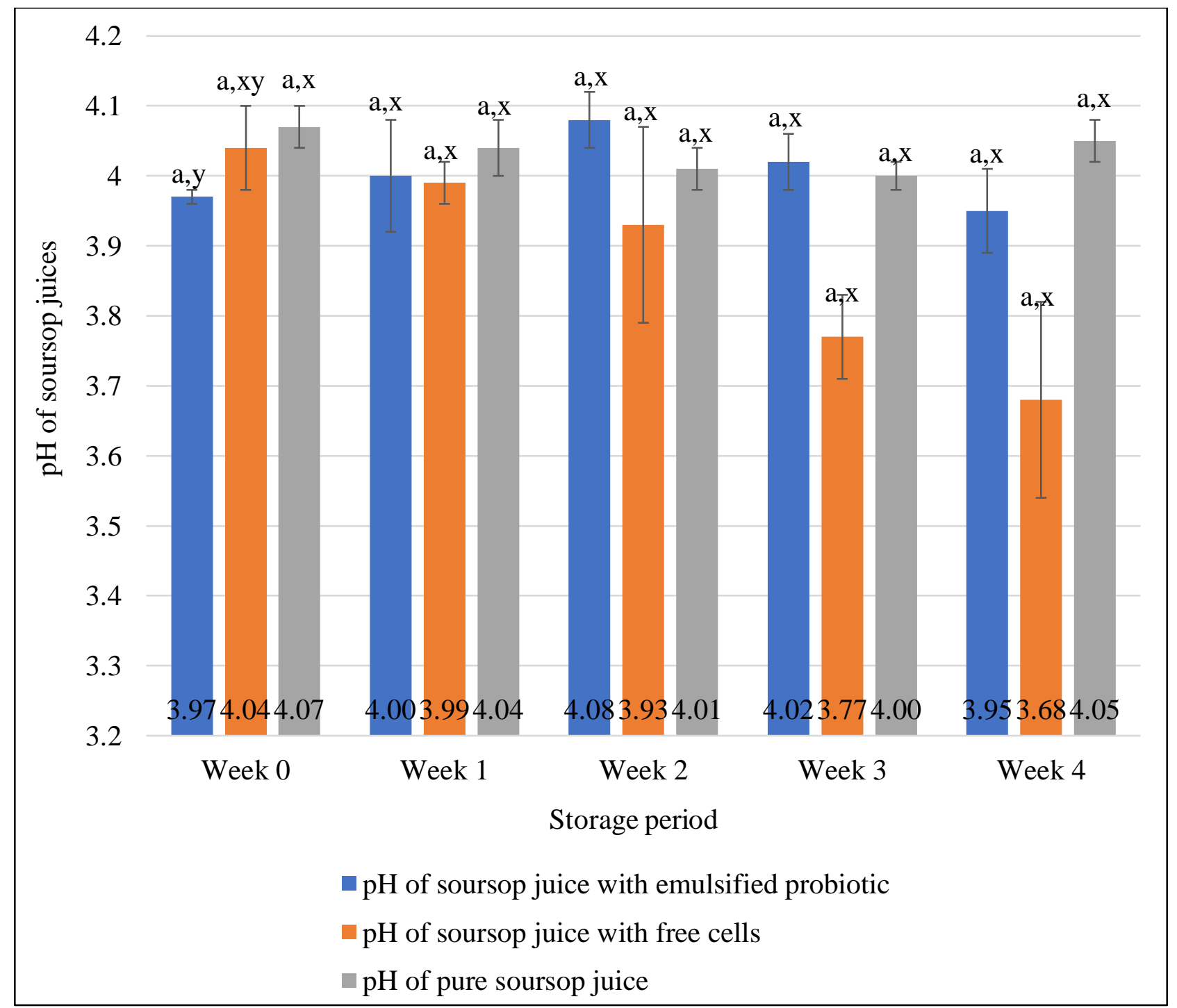

Figure 2. The changes in $\mathrm{pH}$ of soursop juice with emulsified probiotic, soursop juice with free cells and pure soursop juice during storage periods for 4 weeks at $4^{\circ} \mathrm{C}$. Values are mean based on triplicate experiments. Error bar indicate standard deviation of data obtained. Different superscript letters indicate significant different at $\mathrm{p}<0.05$. a-b: significantly different $(\mathrm{p}<0.05)$ within group. $\mathrm{x}-\mathrm{y}$ : significantly different $(\mathrm{p}<0.05)$ between group. 


\section{b) Titratable acidity (TA) changes}

The changes in the titratable acidity (\%) of the soursop juices during storage are shown in Figure 3. The titratable acidity of the soursop juice containing emulsified L. plantarum NBRC 3070 and the pure soursop juice showed no significant difference $(p>0.05)$ throughout the storage period. Meanwhile, a significant difference $(p<0.05)$ in titratable acidity for the soursop juice containing free cells starting from week two of the storage period was recorded. The result of this study demonstrates that the encapsulation of probiotics within double emulsion matrices creates more stable surroundings for probiotics and is able to maintain the acidity of the juice. This may be due to the presence of wall matrices around probiotics which limit the release of acid into the soursop juice.

This finding was agreed with that of Praepanitchai et al. (2019), which reported that the pasteurized mango juice containing encapsulated L. plantarum TISTR 050 showed no significant change in titratable acidity over a period of 35 days of storage at $4^{\circ} \mathrm{C}$. Moreover, Antunes et al. (2013) had demonstrated that there was no significant change in the titratable acidity of the acerola nectar enriched with microencapsulated Bifidobacterium animalis cells over 35 days storage period at $5 \pm 1{ }^{\circ} \mathrm{C}$ with a mean value of $0.29 \pm 0.01$ $\mathrm{g} / 100 \mathrm{~g}$. The insignificant changes $(\mathrm{p}>0.05)$ in the titratable acidity of the pure soursop juice was aligned with the study conducted by Abbo et al. (2006), in which the soursop juice showed a gradual increase in the titratable acidity from week one to week three of storage followed by constant acidity until week seven of storage at $4^{\circ} \mathrm{C}$.

The high titratable acidity in the soursop juice supplemented with free cells towards the end of the storage period may be due to the release of organic acids as by-products by the free cells as a result of fermentation as well as metabolic reactions (Figure 3). The increase in acidity of the soursop juice containing free cells was consistent with the decrease in the $\mathrm{pH}$ of the juice as a result of probiotics metabolic activity within soursop juice. According to Mokhtari et al. (2018), free cells in juice will result in higher acidity from fermentation as compared to encapsulated cells as they have unrestricted access to nutrients such as sugar.

On week three of storage, the titratable acidity of the soursop juice containing emulsified probiotic was significantly lower $(p<0.05)$ than that of the soursop juice supplemented with free cells. This result indicates the release of bacterial metabolites which contributed to the increasing titratable acidity of the soursop juice. On week four, the titratable acidity of the soursop juice containing emulsified probiotic did not show a significant difference $(p>0.05)$ from that of the free cells and pure soursop juices with values of $0.30 \%, 0.57 \%$, and $0.63 \%$ respectively.

\section{c) Total soluble solid (TSS) changes}

The changes in the TSS of the soursop juices during storage at $4^{\circ} \mathrm{C}$ over a period of four weeks are shown in Figure 4. The TSS of the soursop juices which contained emulsified probiotic, free cells, and pure soursop juice ranged from 14.00 ${ }^{\circ}$ Brix to $10.80{ }^{\circ}$ Brix, $14.10{ }^{\circ}$ Brix to $13.63{ }^{\circ}$ Brix, and $14.10{ }^{\circ}$ Brix to $9.30{ }^{\circ}$ Brix respectively. The TSS of the soursop juice incorporated with emulsified probiotic and the pure soursop juice decreased significantly $(p<0.05)$ in week two and week three of storage. The reduction of the TSS in the soursop juice supplemented with emulsified L. plantarum NBRC 3070 may be due to sugar diffusion through the pore of the emulsion matrices for cell consumption. However, the result obtained was in contrast with that of other researchers which reported that the encapsulated $L$. acidophilus and B. lactic only caused small changes $(p>0.05)$ in the TSS of the pasteurized grape juice during storage at $4^{\circ} \mathrm{C}$ for 60 days. This was due to the presence of a membrane which entrapped the probiotic and limited the sugar diffusion into the encapsulation capsule in which it reduced the consumption of readily available sugar in the fruit juice (Mokhtari et al., 2018).

Moreover, the decrement in the TSS may be due to the presence of yeasts in the soursop juice which actively consume the sugar products in the soursop juice for their growth. The significant decrease $(p<0.05)$ in the TSS of the soursop juice containing emulsified probiotic was directly proportional to the significant increase $(\mathrm{p}<0.05)$ in the yeast count during storage. This finding was agreed with that of Ndife et al. (2014) in which the pasteurized pure soursop juice showed a significant reduction in the TSS from $14.32^{\circ}$ Brix to $10.72^{\circ} \mathrm{Brix}$ over a refrigerated storage period of eight weeks due to the presence of 
microorganisms, mainly yeasts, which utilized the sugar in the juice.

Meanwhile, the TSS in the soursop juice containing free cells was significantly higher $(p<0.05)$ than that of the soursop juice supplemented with emulsified probiotic in week four of storage (Figure 4). The low viability of free cells in week four may contribute to high TSS of soursop juice since fewer cells were available to consume the sugar products in the juice.

\section{d) Viscosity changes}

The changes in the viscosity of the soursop juices during storage at $4^{\circ} \mathrm{C}$ for four weeks are shown in Figure 5 . The result showed a $45 \%$ reduction in the viscosity of the soursop juice incorporated with emulsified L. plantarum NBRC 3070 starting from week one to week four. As compared to the soursop juice with free cells and its pure form, which had a reduction in the viscosity of $71.5 \%$ and $12.5 \%$ respectively. The reduction of the viscosity of the juice with emulsified probiotic may be due to the utilization of sugar by the yeast present in the juice as discussed previously (Table 2). This also leads to the reduction of the TSS in the juice (Figure 4). Meanwhile, the viscosity of the soursop juice with free cells was highly reduced due to the presence of free cells in the juice which freely utilized the soluble sugar. According to Juszczak et al. (2010), the presence of a high concentration of dissolved solutes such as sugar in the solution contributes to an increase in the viscosity due to a high number of hydrogen bonding with the hydroxyl groups, but high utilization of the component can lead to a reduction in viscosity of the medium.

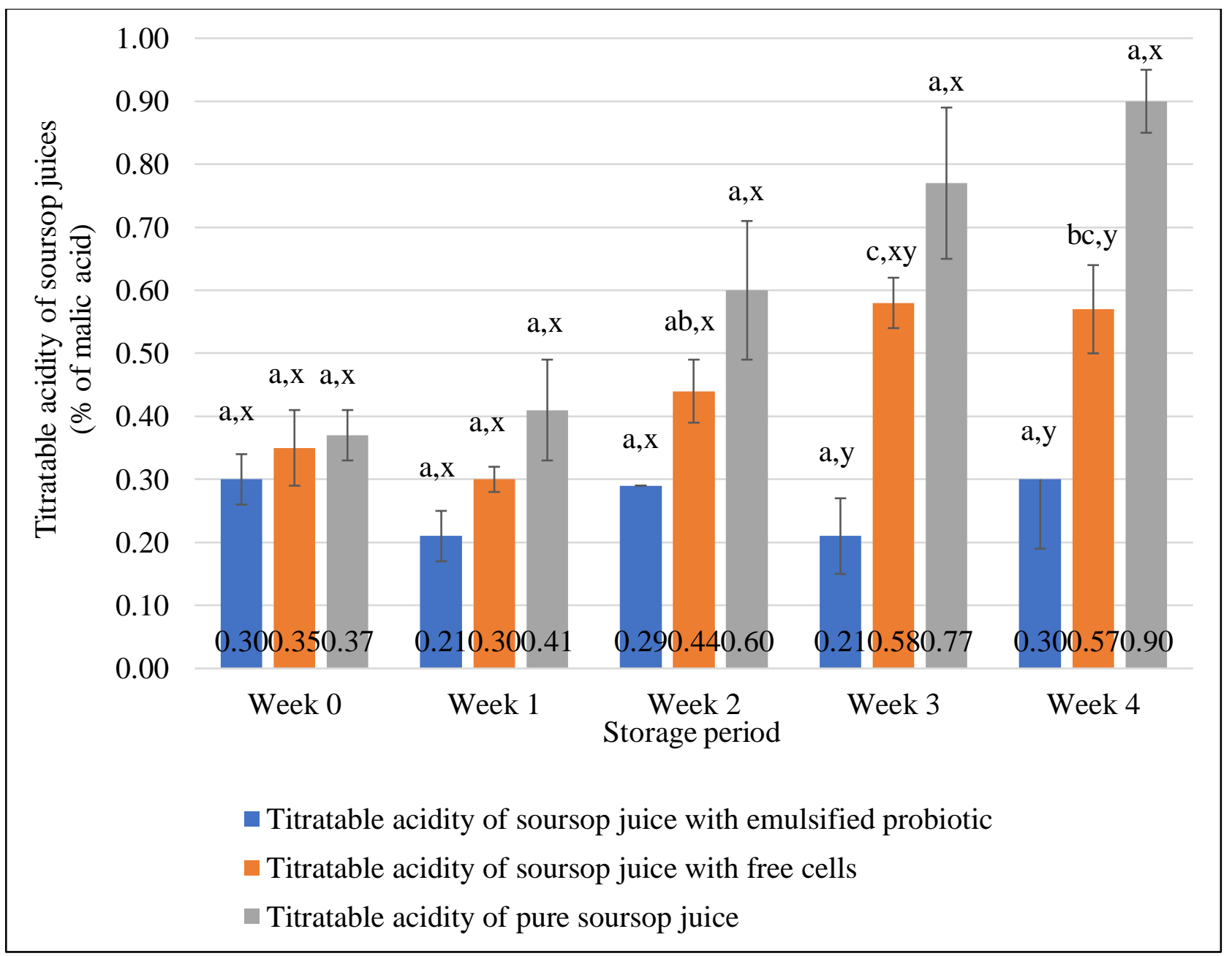

Figure 3. The changes in titratable acidity of soursop juice with emulsified probiotic, soursop juice with free cells, and pure soursop juice during storage periods for 4 weeks at $4^{\circ} \mathrm{C}$. Values are mean based on triplicate experiments. Error bar indicate standard deviation of data obtained. Different superscript letters indicate significant different at $\mathrm{p}<0.05$. a-c: significantly different $(\mathrm{p}<0.05)$ within group. $\mathrm{x}-\mathrm{y}$ : significantly different $(\mathrm{p}<0.05)$ between group. 


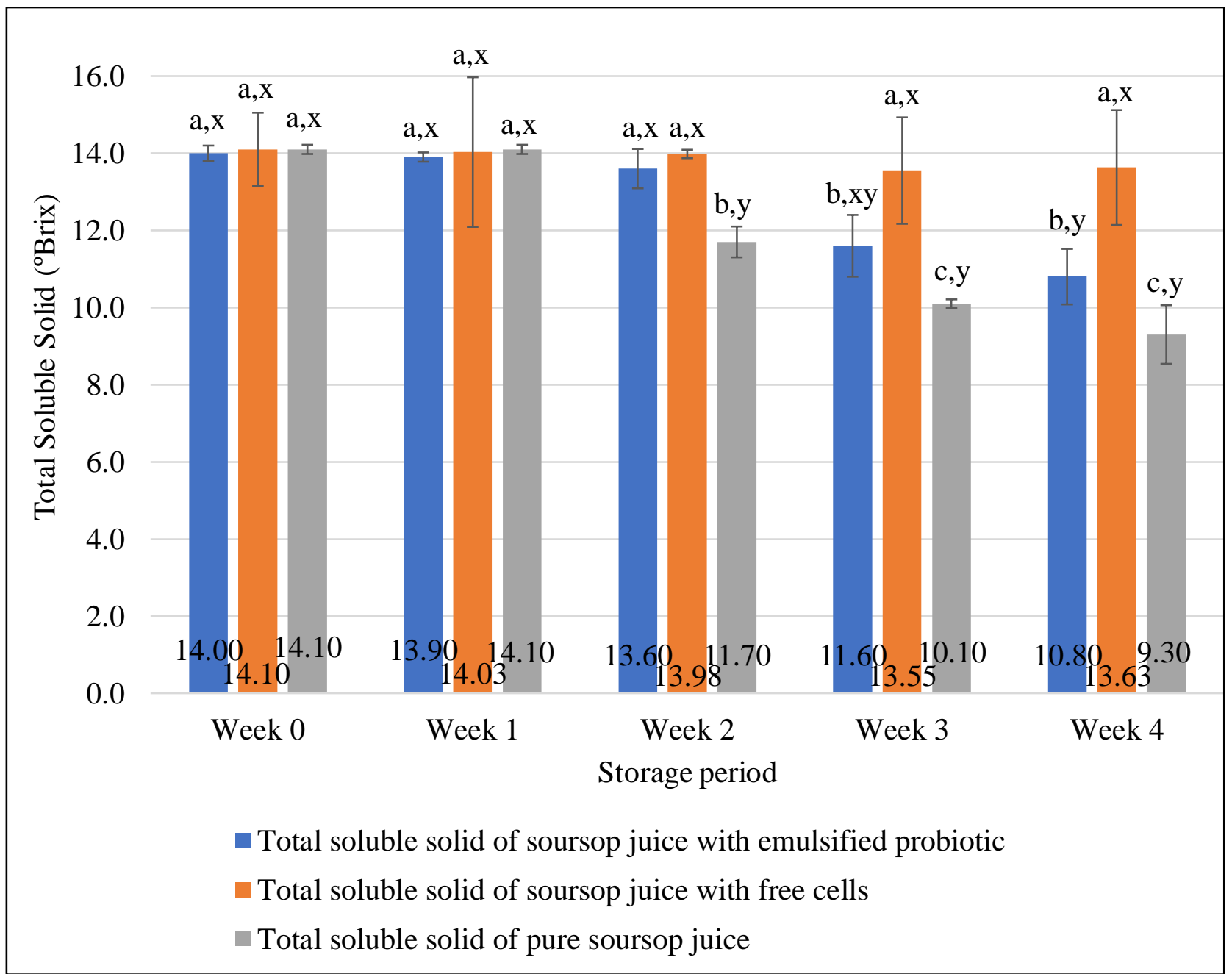

Figure 4. The changes in total soluble solid of soursop juice with emulsified probiotic, soursop juice with free cells, and pure soursop juice during storage periods for 4 weeks at $4^{\circ} \mathrm{C}$. Values are mean based on triplicate experiments. Error bar indicate standard deviation of data obtained. Different superscript letters indicate significant different at $\mathrm{p}<0.05$. a-c: significantly different $(\mathrm{p}<0.05)$ within group. $\mathrm{x}-\mathrm{y}$ : significantly different $(p<0.05)$ between group.

\section{e) Colour changes}

The changes in the colour of the soursop juices during storage at $4^{\circ} \mathrm{C}$ for four weeks are shown in Table 3. There was a significant increase $(\mathrm{p}<0.05)$ in the $+\mathrm{L}^{*}$ values and $+\mathrm{b}^{*}$ values of the double emulsified L. plantarum NBRC 3070 soursop juice during the storage period with values ranging from 43.68 to 55.53 and 1.22 to 4.64 respectively. The pure soursop juice also showed a similar trend in both the $+\mathrm{L}^{*}$ and $+\mathrm{b}^{*}$ values, which ranged from 48.42 to 55.91 and 4.26 to 8.26 respectively. In this study, the high $L^{*}$ value of the soursop juice containing emulsified probiotic that was observed on week zero may be due to the insertion of emulsion which contributes to the increase in the lightness of the soursop juice.

Meanwhile, the presence of yellowish tint in the juice was indicated by the $+b^{*}$ value which may be due to high enzymatic activity (Oliveira $e t$ al., 2016). The result of this study showed a significant difference $(\mathrm{p}<0.05)$ in the $+\mathrm{b}^{*}$ values which were recorded weekly for the soursop juice containing emulsified probiotic and the pure soursop juice which acted as a control throughout the storage period. The soursop juice containing emulsified probiotic with $a+b$ value of 4.64 at the end of storage period was significantly lower $(p<0.05)$ than that of the pure soursop juice, which had $a+b$ value of 8.26 . This may indicate that the enzymatic reaction that occurs in the emulsified probiotic soursop juice is lower than that of the pure soursop juice.

In contrast, the $-\mathrm{a}^{*}$ values for the soursop juice containing emulsified probiotic which 
corresponded to the colour measurement of greenness showed insignificant difference $(p>0.05)$ throughout the storage period, whereas a significant difference of the $-a^{*}$ values $(p<0.05)$ in the pure soursop juice was observed at the beginning of week two of storage. The result of this study indicates that the emulsified probiotic soursop juice is able to maintain the greenish colour of the juice throughout the storage period. According to Qudsieh et al. (2002), the decrease in the $-a^{*}$ value of the pure soursop juice in this study might be due to the decline in the chlorophyll content in the juice as the storage period progressed.

The colour characteristics of the soursop juice containing emulsified probiotic on week four of storage which showed a light colour, with green and yellowish intensity, were indicated by a $+\mathrm{L}^{*}$ value of $55.53,-\mathrm{a}^{*}$ value of -2.07 , and $+\mathrm{b}^{*}$ value of 4.64 respectively. This finding was agreed with that of Sawant and Dongre (2014), which reported a similar range of colour characteristics for the soursop pulp.

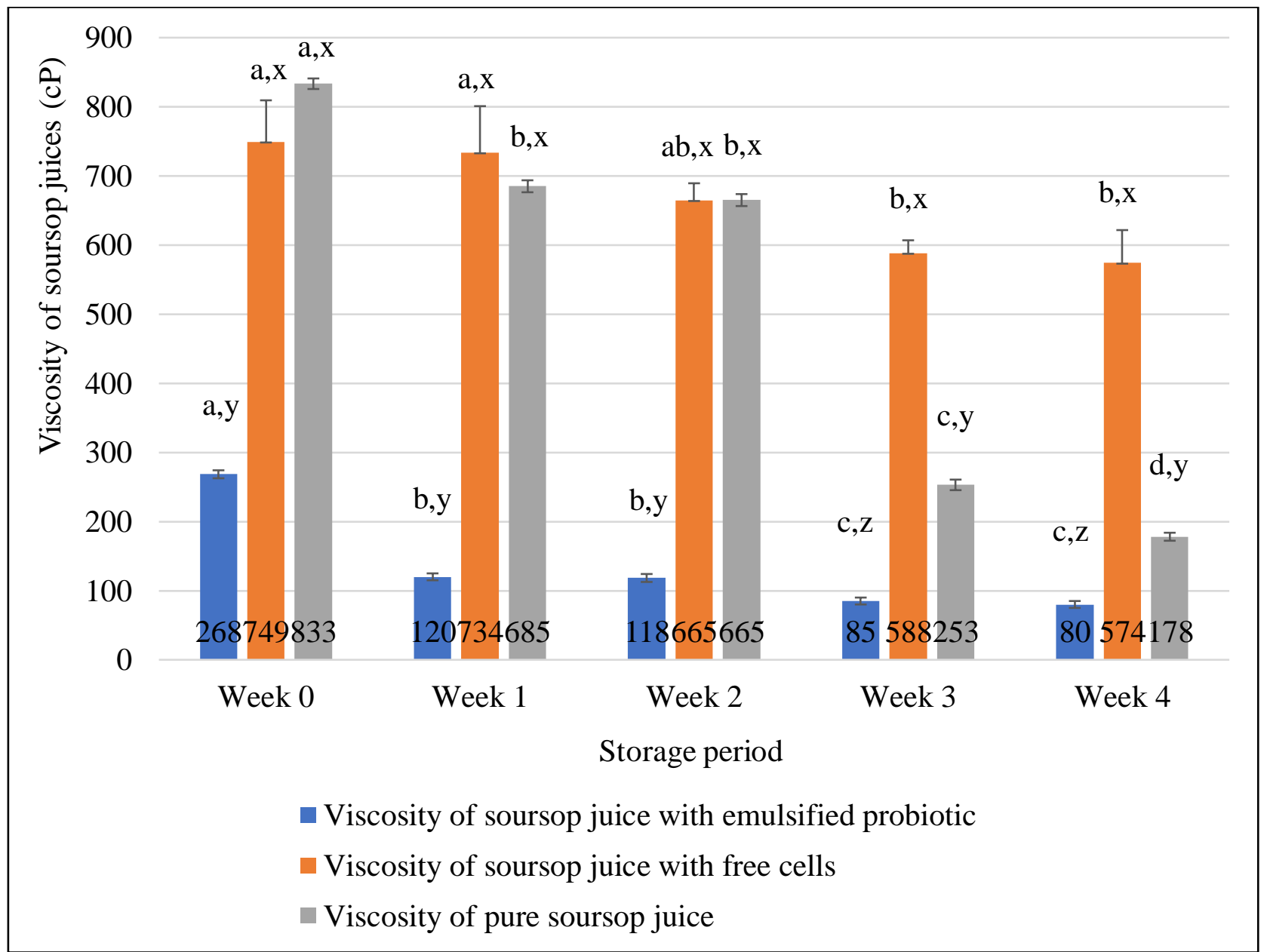

Figure 5. The changes in viscosity of soursop juice with emulsified probiotic, soursop juice with free cells, and pure soursop juice during storage periods for 4 weeks at $4^{\circ} \mathrm{C}$. Values are mean based on triplicate experiments. Error bar indicate standard deviation of data obtained. Different superscript letters indicate significant different at $\mathrm{p}<0.05$. a-d: significantly different $(\mathrm{p}<0.05)$ within group. $\mathrm{x}-\mathrm{z}$ : significantly different $(\mathrm{p}<0.05)$ between group. 
Table 3. Color of $\mathrm{L}^{*}, \mathrm{a}^{*}$ and $\mathrm{b}^{*}$ value for soursop juice incorporated with emulsified L. plantarum NBRC 3070 during storage.

\begin{tabular}{|c|c|c|c|c|c|c|}
\hline \multicolumn{3}{|c|}{ L* value } & \multicolumn{2}{|c|}{ a* Value } & \multicolumn{2}{|c|}{ b* Value } \\
\hline $\begin{array}{l}\text { Storage } \\
\text { Period } \\
\text { (Weeks) }\end{array}$ & $\begin{array}{c}\text { Soursop Juice with } \\
\text { Emulsified } \\
\text { Probiotic }\end{array}$ & $\begin{array}{l}\text { Control Pure } \\
\text { Soursop Juice }\end{array}$ & $\begin{array}{l}\text { Soursop Juice with } \\
\text { Emulsified Probiotic }\end{array}$ & $\begin{array}{l}\text { Control Pure } \\
\text { Soursop Juice }\end{array}$ & $\begin{array}{l}\text { Soursop Juice with } \\
\text { Emulsified Probiotic }\end{array}$ & $\begin{array}{l}\text { Control Pure } \\
\text { Soursop Juice }\end{array}$ \\
\hline Week 0 & $43.68 \pm 0.61^{c, y}$ & $48.42 \pm 0.40^{c, x}$ & $-1.68 \pm 0.29^{\mathrm{a}, \mathrm{y}}$ & $-1.43 \pm 0.26^{\mathrm{a}, \mathrm{x}}$ & $1.22 \pm 0.34^{\mathrm{b}, \mathrm{y}}$ & $4.26 \pm 0.41^{\mathrm{c}, \mathrm{x}}$ \\
\hline Week 1 & $51.42 \pm 0.90^{\mathrm{b}, \mathrm{y}}$ & $48.37 \pm 0.62^{c, x}$ & $-1.74 \pm 0.46^{\mathrm{a}, \mathrm{x}}$ & $-1.65 \pm 0.07^{\mathrm{a}, \mathrm{x}}$ & $1.60 \pm 0.33^{\mathrm{b}, \mathrm{y}}$ & $4.43 \pm 0.25^{\mathrm{c,x}}$ \\
\hline Week 2 & $52.09 \pm 0.02^{\mathrm{b}, \mathrm{y}}$ & $54.52 \pm 0.02^{\mathrm{b}, \mathrm{x}}$ & $-1.89 \pm 0.03^{\mathrm{a,y}}$ & $-2.07 \pm 0.01^{\mathrm{b}, \mathrm{x}}$ & $2.00 \pm 0.25^{\mathrm{b}, \mathrm{y}}$ & $5.79 \pm 0.46^{\mathrm{b}, \mathrm{x}}$ \\
\hline Week 3 & $55.71 \pm 0.38^{\mathrm{a}, \mathrm{x}}$ & $54.91 \pm 0.01^{\mathrm{b}, \mathrm{x}}$ & $-2.13 \pm 0.09^{\mathrm{a}, \mathrm{x}}$ & $-2.05 \pm 0.05^{\mathrm{b}, \mathrm{x}}$ & $2.46 \pm 0.77^{\mathrm{b}, \mathrm{y}}$ & $5.62 \pm 0.10^{\mathrm{b}, \mathrm{x}}$ \\
\hline Week 4 & $55.53 \pm 0.25^{\mathrm{a}, \mathrm{x}}$ & $55.91 \pm 0.01^{\mathrm{a}, \mathrm{x}}$ & $-2.07 \pm 0.04^{\mathrm{a}, \mathrm{y}}$ & $-2.15 \pm 0.02^{\mathrm{b}, \mathrm{x}}$ & $4.64 \pm 0.55^{\mathrm{a}, \mathrm{y}}$ & $8.26 \pm 0.40^{\mathrm{a}, \mathrm{x}}$ \\
\hline
\end{tabular}

Values are mean based on triplicate experiments. Symbol $( \pm)$ indicate standard deviation of data obtained. Different superscript letters indicate significant different at $\mathrm{p}<0.05$. a-c: significantly different $(p<0.05)$ by column.

$\mathrm{x}-\mathrm{y}$ : significantly different $(\mathrm{p}<0.05)$ by row.

Table 4. Sensory evaluation of soursop juice incorporated with emulsified L. plantarum NBRC 3070 by 35 independent panels.

\begin{tabular}{|c|c|c|c|c|c|c|c|c|c|c|}
\hline \multirow[t]{2}{*}{ Week } & \multicolumn{2}{|c|}{ Color } & \multicolumn{2}{|c|}{ Viscosity } & \multicolumn{2}{|c|}{ Odor } & \multicolumn{2}{|c|}{ Taste } & \multicolumn{2}{|c|}{ Overall Acceptability } \\
\hline & $\begin{array}{c}\text { Soursop } \\
\text { Juice with } \\
\text { Emulsified } \\
\text { Probiotic } \\
\end{array}$ & Control & $\begin{array}{c}\text { Soursop } \\
\text { Juice with } \\
\text { Emulsified } \\
\text { Probiotic } \\
\end{array}$ & Control & $\begin{array}{l}\text { Soursop } \\
\text { Juice with } \\
\text { emulsified } \\
\text { probiotic }\end{array}$ & Control & $\begin{array}{c}\text { Soursop } \\
\text { Juice with } \\
\text { Emulsified } \\
\text { Probiotic }\end{array}$ & Control & $\begin{array}{c}\text { Soursop } \\
\text { Juice with } \\
\text { Emulsified } \\
\text { Probiotic } \\
\end{array}$ & Control \\
\hline 0 & $6.71 \pm 1.45^{a}$ & $6.54 \pm 1.44^{\mathrm{ab}}$ & $6.26 \pm 1.44^{\mathrm{ab}}$ & $6.74 \pm 1.09^{\mathrm{a}}$ & $5.40 \pm 1.69^{c}$ & $6.60 \pm 1.52^{\mathrm{b}}$ & $5.97 \pm 1.87^{\mathrm{bc}}$ & $6.54 \pm 1.77^{\mathrm{b}}$ & $6.23 \pm 1.60^{\mathrm{bc}}$ & $6.97 \pm 1.42^{\mathrm{ab}}$ \\
\hline 4 & $5.81 \pm 1.78^{\mathrm{b}}$ & $6.51 \pm 1.50^{\mathrm{ab}}$ & $5.86 \pm 1.50^{\mathrm{b}}$ & $6.54 \pm 1.46^{\mathrm{ab}}$ & $4.66 \pm 1.83^{c}$ & $6.28 \pm 1.70^{\mathrm{b}}$ & $4.20 \pm 2.01^{\mathrm{d}}$ & $5.20 \pm 2.17^{c}$ & $4.86 \pm 1.80^{\mathrm{d}}$ & $5.57 \pm 1.90^{\mathrm{cd}}$ \\
\hline
\end{tabular}




\section{f) Sensory evaluation on soursop juice incorporated with emulsified $L$. plantarum NBRC 3070}

In the sensory evaluation, there were five criteria involved, which were colour, viscosity, odour, taste, and overall acceptability of the juice. The data were collected based on the standard scale of sensory (9-point Hedonic Scale) preferred by the independent panels. As shown in Table 4, the sensory criteria of the samples were compared between week zero and week four of storage. Generally, all criteria in the sensory evaluation reduced from week zero to week four. However, the reduction was not significantly different ( $p>0.05)$ except for overall acceptability.

The reduction of the colour quality may be due to the insertion of emulsion. The lightness appearance of the juice is believed to have high influence on the consumers' acceptance. Meanwhile, the consumers showed low acceptance for the colour attribute of the soursop juice with emulsified probiotic on week four due to the "oiling off" effect on the top of the product caused by the destabilization of the double emulsion as the storage period progressed. Also, the reduction in viscosity preference by the panels on week four indicated that the products had lost its colloidal system stabilization during storage which contributed the mouthfeel effect of the product during the sensory evaluation (SegoviaBravo et al., 2012).

As for the odour criteria, the presence of probiotics in the soursop juice may contribute to the release of unpleasant odour as a result of the metabolic reaction. This statement is agreed with that of Pimentel (2017), who reported that the addition of probiotic cultures in juices can alter the sensory characteristics due to the liberation of unpleasant odour. Based on the previous research by Malganji et al. (2016), the pure grape juice had a better odour than the one containing probiotics. On the other hand, the soursop juice with emulsified probiotic showed the least score for the taste quality and this may be related to the significant decreased in the TSS of the soursop juice incorporated with emulsified L. plantarum NBRC 3070 as the storage period progressed. This is because the decrease in TSS will reduce the sweetness of juices. Moreover, the use of polyglycerol polyricinoleate (PGPR) as an emulsifier in the primary emulsion also contributed to the unpleasant "off-taste" which was detected by the consumers (Muschiolik and Dickinson, 2017). In this study, the overall acceptability was taken for further consideration of improvement due to the significant difference $(p<0.05)$ between week zero and week four. The overall acceptability for the emulsified probiotic soursop juice can be improved by the addition of preservative, colouring, flavouring, and additive sugar in the formulation of juice such as commercial juices which are available in the market.

\section{CONCLUSION}

In conclusion, L. plantarum NBRC 3070 was successfully emulsified into the soursop juice with double (W1/O/W2) emulsion with an emulsion efficiency of $86.02 \%$. Double emulsion of $L$. plantarum NBRC 3070 was proven to be able to protect the cells from the acidic environment of the juice during storage. However, the microbiological and physicochemical of the juice were changed upon addition to the juice. The presence of yeast in the juice containing emulsified probiotic affected the TSS and viscosity. Further improvement needs to be carried out in order to ensure good quality of soursop juice incorporated with probiotic. Meanwhile, the sensory evaluation of the juice presented a promising result. Nevertheless, future developments on probiotic soursop juices are also needed in order to improve customers' preferences to juices with probiotics.

\section{REFERENCES}

Abbo, E. S., Olurin, T. O., \& Grace, O. G. 2006. Studies on the storage stability of soursop (Annona muricata L.) juice. African Journal of Biotechnology 5(19): 1808-1812.

Akpeji, S. C., Adebayo-tayo, B. C., Sanusi, J. F., \& Alao, S. O. 2017. Production and properties of probiotic soursop juice using Pediococcus pentosaceus LBF2 as starter. International Journal of Biochemistry Research \& Review 17(2): 1-10.

Ampofo-Asiama, J., \& Quaye, B. 2018. Effect of storage temperature on the physicochemical, nutritional, and microbiological quality of pasteurised soursop (Annona muricata L.) juice. African Journal of Food Science 13(2): 38-47.

Antunes, A. E. C., Liserre, A. M., Coelho, A. L. A., Menezes, C. R., Moreno, I., Yotsuyanagi, K., \& Azambuja, N. C. 2013. 
Acerola nectar with added microencapsulated probiotic. LWT - Food Science and Technology 54(1): 125-131.

Braide, W., Oranusi, S. U., \& Otali, C. C. 2012. Microbiological status of processed fruit juice sold in the commercial city of Onitsha. Scholarly Journal of Biological Science 1(3): 25-30.

Cofrades, S., Antoniou, I., Solas, M. T., Herrero, A. M., \& JiménezColmenero, F. 2013. Preparation and impact of multiple (water-in-oil-in-water) emulsions in meat systems. Food Chemistry 141(1): 338-346.

De Almeida Paula, D., Martins, E. M. F., De Almeida Costa, N., De Oliveira, P. M., de Oliveira, E. B., \& Ramos, A. M. 2019. Use of gelatin and gum arabic for microencapsulation of probiotic cells from Lactobacillus plantarum by a dual process combining double emulsification followed by complex coacervation. International Journal of Biological Macromolecules 133: 722-731.

Ding, W. K., \& Shah, N. P. 2008. Survival of free and microencapsulated probiotic bacteria in orange and apple juices. International Food Research Journal 15(2): 219-232.

El-Kadri, H., Lalou, S., Mantzouridou, F., \& Gkatzionis, K. 2018. Utilisation of water-in-oil- water (W1/O/W2) double emulsion in a set-type yogurt model for the delivery of probiotic Lactobacillus paracasei. Food Research International 107: 325-336.

El-Kadri, H., Overton, T., \& Gkatzionis, K. 2016. Understanding and controlling the release mechanism of Escherichia coli in double W1/O/W2 emulsion globules in the presence of $\mathrm{NaCl}$ in the W2 phase. RSC Advances 5(127): 105098105110.

Fernandes Pereira, A. L., \& Rodrigues, S. 2018. Turning Fruit Juice into Probiotic Beverages. In: Fruit Juices. Rajauria, G., \& Tiwari, B. K. pp. 279-287. San Diego, CA, USA: Academic Press.

Food and Agriculture Organization of the United Nations, World Health Organization (WHO/FAO). 2002. Probiotics in food: Health and nutritional properties and guidelines for evaluation. Report of a joint FAO/WHO working group on drafting guidelines for the evaluation of probiotics in food. FAO Food and Nutrition Paper 85. Retrieved from http://www.fao.org/3/a-a0512e.pdf.

Gamage, S. M., Mihirani, M. K. S., Perera, O. D. A. N., \& Weerahewa, H. L. D. 2016. Development of synbiotic beverage from beetroot juice using beneficial probiotic Lactobacillus casei 431. Rubuna Journal of Science 7: 64-69.

Horackova, S., Rokytova, K., Bialasova, K., Klijdova, I., \& Slukova, M. 2018. Fruit juices with probiotics - new type of functional foods. Czech Journal of Food Science 36: 284-288.

Juszczak, L., Witczak, M., Fortuna, T., \& Solarz, B. 2010. Effect of temperature and soluble solids content on the viscosity of beetroot (Beta vulgaris) juice concentrate. International Journal of Food Properties 13(6): 1364-1372.

Kailasapathy, K., \& Chin, J. 2000. Survival and therapeutic potential of probiotic organisms with reference to Lactobacillus acidophilus and Bifidobacterium spp. Immunology \& Cell Biology 78(1): 80-88.

Khalil, K. A., Mustafa, S., Mohammad, R., Ariff, A. B., Ahmad, S. A., Dahalan, F. A., \& Abdul Manap, M. Y. 2019. Encapsulation of Bifidobacterium pseudocatenulatum Strain G4 within bovine gelatin-genipin-sodium alginate combinations: Optimisation approach using face central composition design-response surface methodology (FCCD-RSM). International Journal of Microbiology 2019: 1-11.

Krasaekoopt, W., Bhandari, B., \& Deeth, H. 2003. Evaluation of encapsulation techniques of probiotics for yoghurt. International Dairy Journal 13: 2-13.

Lizasoain, A., Tort, L. F., Garcia, M., Gomez, M. M., Leite, J. P., Miagostovich, M. P., \& Victoria, M. 2015. Stability of double emulsion for food application. Journal of Applied Microbiology 119(3): 859-867.

Lopez-Rubio, A., Gavara, R., \& Lagaron, J. M. 2006. Bioactive packaging: turning foods into healthier foods through biomaterials. Trends in Food Science \& Technology 17(10): 567575 .

Malganji, S., Sohrabvandi, S., Jahadi, M., Nematollahi, A., \& Sarmadi, B. 2016. Effect of refrigerated storage on sensory properties and viability of probiotic in grape drink. Applied Food Biotechnology 3(1): 59-62.

Minh, N. P., Pham, V. T., Thang, C. V., Canh, N. M., Tien, V. K., \& Trinh, T. V. 2019. Technical parameters affecting the production of soursop (Annona muricata) juice. Journal of Pharmaceutical Sciences and Research 11(3): 1068-1072.

Mokhtari, S., Jafari, S. M., \& Khomeiri, M. 2018. Survival of encapsulated probiotics in pasteurized grape juice and evaluation of their properties during storage. Food Science and Technology International 2-10.

Mombelli, B., \& Gismondo, M.R. 2000. The use of probiotics in medical practice. International Journal of Antimicrobial Agents 16: 531-536.

Muschiolik, G., \& Dickinson, E. 2017. Double emulsions relevant to food systems: Preparation, stability, and applications. Comprehensive Reviews in Food Science and Food Safety 16(3): $532-555$.

Ndife, J., Kwaya, P. J., \& Bello, S. 2014. Production and evaluation of storage changes in soursop juice. Asian Journal of Agriculture and Food Sciences 2(5).

Okwulehie, I. C., \& Alfred, N. K. 2010. Fungi associated with deterioration of soursop (Anona muricata. Linn) fruits in Abia State, Nigeria. African Journal of Microbiology Research 4(3): 143-146.

Oliveira, E. N. A. D., Santos, D. D. C., Santos, Y. M. G. D., Buchweitz, P. R., \& Gomes, J. P. 2016. Soursop liquor processing: influence of the process variables on the physical and chemical characteristics. Revista Caatinga 29(1): 246-256.

Phrompthep, K., \& Leenanon, B. 2017. Survivability of immobilized Lactobacillus plantarum cells within bacterial cellulose in mamao juice. International Food Research Journal 24(3): 939-949.

Pimentel, T. C. 2017. Fruit juices as probiotic carriers. Journal of Plant Biotechnology and Microbiology 1(1): 8-10.

Pimentel-González, D. J., Campos-Montiel, R. G., LobatoCalleros, C., Pedroza-Islas, R., \& Vernon-Carter, E. J. 2009. Encapsulation of Lactobacillus rhamnosus in double emulsions formulated with sweet whey as emulsifier and survival in simulated gastrointestinal conditions. Food Research International 42(2): 292-297.

Praepanitchai, O. A., Noomhorm, A., \& Anal, A. K. 2019. Survival and behavior of encapsulated probiotics (Lactobacillus plantarum) in calcium-alginate-soy protein isolate-based hydrogel beads in different processing conditions $(\mathrm{pH}$ and temperature) and in pasteurized mango juice. BioMed Research International 2019: 1-8.

Qudsieh, H. Y. M., Yusof, S., Osman, A., \& Rahman, R. A. 2002. Effect of maturity on chlorophyll, tannin, color, and polyphenol oxidase (PPO) activity of sugarcane juice (Saccharumofficinarum var. yellow cane). Journal of Agricultural and Food Chemistry 50(6): 1615-1618.

Rathod, P. S. 2017. Development of probiotic beverage based on apple and orange juice (Master dissertation). Retrieved from http://krishikosh.egranth.ac.in/handle/1/5810037376.

Safiah, S. H., Intan, N. A. F., Yusoff, A., \& Khalil, K. A. 2020. A review on microencapsulation in improving probiotic stability for beverages application. Science Letter 4(1): 49-61.

Sawant, T. P., \& Dongre, R. S. 2014. Bio-chemical compositional analysis on Annona muricata: A miracle fruit's review. 
International Journal of Universal Pharmacy and Bio Sciences 3(2): $82-104$.

Segovia-Bravo, K. A., Guignon, B., Bermejo-Prada, A., Sanz, P. D., \& Otero, L. 2012. Hyperbaric storage at room temperature for food preservation: A study in strawberry juice. Innovative Food Science \& Emerging Technologies 15: 14-22.

Silva, S. B., \& Ferrari, J. 2016. Development of probiotic grape juice and Lactobacillus paracasei viability under cold storage. X CIGC Section IV International Technical Symposium. XXV Congresso Brasileiro de Ciência e Tecnologia de Alimentos.

Stanton, C., Ross, R. P., Fitzgerald, G. F., \& Sinderen, D. V. 2005. Fermented functional foods based on probiotics and their biogenic metabolites. Current Opinion in Biotechnology 16(2): 198-203.

Tee, W., Nazaruddin, R., Tan, Y., \& Ayob, M. 2013. Effects of encapsulation on the viability of potential probiotic Lactobacillus plantarum exposed to high acidity condition and presence of bile salts. Food Science and Technology International 20(6): 399-404.

US Food and Drug Administration (US-FDA). 2017. Potential for infiltration, survival, and growth of human pathogens within fruits and vegetables. Retrieved from https://www.fda.gov/food/hazard-analysis-criticalcontrol-point-haccp/potential-infiltration-survival-andgrowth-human-pathogens-within-fruits-and-vegetables 